\title{
Temperature and pressure tolerances of embryos and larvae of the Antarctic sea urchin Sterechinus neumayeri (Echinodermata: Echinoidea): potential for deep-sea invasion from high latitudes
}

\author{
Paul A. Tyler ${ }^{1, *}$, Craig M. Young ${ }^{2}$, Andrew Clarke ${ }^{3}$ \\ ${ }^{1}$ School of Ocean and Earth Science, University of Southampton, SOC, Southampton SO14 3Z, United Kingdom \\ ${ }^{2}$ Department of Larval Ecology, Harbor Branch Oceanographic Institution, 5600 US 1 N, Ft. Pierce, Florida 34946, USA \\ ${ }^{3}$ Britísh Antarctic Survey, High Cross Madingley Road, Cambridge CB3 0ET, United Kingdom
}

\begin{abstract}
Early embryos, blastulae, prisms and 4-arm plutei of the Antarctic shallow-water echinoid Sterechinus neumayeri were subjected to a temperature/pressure regime from -1.2 to $+2.5^{\circ} \mathrm{C}$ and from 1 to $250 \mathrm{~atm}$. Early embryos were able to tolerate pressures up to $150 \mathrm{~atm}$ at +2.5 to $+0.9^{\circ} \mathrm{C}$ and $100 \mathrm{~atm}$ at $-1.2^{\circ} \mathrm{C}$. Blastulae and prisms showed an increasing sensitivity to pressure with decreasing temperature. Four-arm plutei were more sensitive than early larval stages to pressure and were also more sensitive to pressure at lower temperatures. These data suggest that the embryonic and larval stages of $S$. neumayeri are capable of surviving low temperatures in surface waters, but only tolerate higher pressures when water column temperatures are $>0^{\circ} \mathrm{C}$. Such a pattern of temperature increase is seen in the formation of Antarctic Bottom Water in the Weddell Sea and we infer that the larvae of S. neumayeri are capable of penetrating the deep sea through the agency of this deep water formation.
\end{abstract}

KEY WORDS: Sterechinus · Antarctica · Deep sea $\cdot$ Larvae $\cdot$ Pressure $\cdot$ Temperature

\section{INTRODUCTION}

The origin of the modern deep-sea fauna remains controversial, in part because the various hypotheses advanced over the past century do not lend themselves to rigorous experimental testing. Definitive answers cannot be obtained, as the presumed invasion, extinction and vicariance events that resulted in the modern deep-sea fauna took place in the past and cannot be directly observed. Evidence, mostly correlative in nature, is of necessity based on the biogeographic and bathymetric distributions, and phylogenetic relationships, of extant species. A fundamental premise of virtually every hypothesis is that thermal tolerances of organisms invading the deep sea were, and remain, narrow and conservative. If this assumption is true, then, recent invasions of the deep sea

•E-mail: pat8@soc.soton.ac.uk from shallow water should have occurred only through cold, near-isothermal water columns at high latitudes (Kussakin 1973, Menzies et al. 1973). From a physiological standpoint, this explanation is the most parsimonious, since animals in polar seas are preadapted to the thermal conditions of the present deep sea. Alternatively, however, animals could have invaded the deep sea even at low latitudes during the late Mesozoic or early Cenozoic when the ocean was vertically homogenous and warm (Menzies et al. 1973, Hessler \& Wilson 1983, Young et al. 1997). The vertical pressure gradient in the sea is the longest continuous environmental gradient on earth. Pressure increases by $10^{5} \mathrm{~Pa}(1 \mathrm{~atm}$ or bar) with every $10 \mathrm{~m}$ increase in depth. By contrast, vertical thermal gradients are variable, and may be short and abrupt, especially near discontinuity layers. Pressure affects the growth and survival of a number of deep-sea organisms from bacteria to metazoans (see Gage \& Tyler 1991) in all life-history stages. 
Early studies of the effect of pressure on embryonic development were driven by an interest in the properties of the mitotic spindle and cell membranes (Marsland 1970). A pressure of $275 \times 10^{5} \mathrm{~Pa}(\sim 275 \mathrm{~atm})$ was found to inhibit division of zygotes of shallow-water sea urchins (Marsland 1938, 1950, 1970, Zimmermann \& Marsland 1964, Swezwy et al. 1987). More recently, the physiological effects of pressure have been studied extensively (reviewed by Somero 1992) and pressure has been implicated as an important ecological factor that limits vertical distributions of animals in the sea (Kinne 1972, Carney et al. 1983).

The pressure and temperature tolerances of echinoderm (mainly echinoid) embryos, from both deep- and shallow-water adults, have been determined for species living in Hawaii, the Bahamas, the northern Mediterranean and the deep and shallow North Atlantic (Young \& Tyler 1993, Young et al. 1996a,b, 1997, Tyler \& Young 1998). The species from the North Atlantic and the northern Mediterranean were chosen because deep-water formation (North Atlantic Deep Water and Western Mediterranean Deep Water, respectively) is known to occur in these areas (Gage \& Tyler 1991). The data suggest that the larvae of shallow-water echinoids are sufficiently tolerant of high pressures to follow an isothermal layer into, at least, bathyal depths and could, therefore, send colonists to the deep sea within a single generation. We have also shown (Tyler \& Young 1998) that embryonic pressure tolerances of bathyal Echinus acutus var norvegicus are broader than those of shallow-water conspecifics, suggesting that this species may presently be invading the deep sea by slowly adapting to increased pressure. In the North Atlantic the vertically overlapping species of Echinus have retained both planktotrophy and seasonal reproduction at all depths from the intertidal zone to the abyssal plain (Tyler et al. 1996). This evidence supports the hypothesis that at least 1 genus of echinoid radiated into the deep sea from an origin in shallow water.

Although the deepest waters in the world's ocean (Antarctic Bottom Water) originate from shallow water around the Antarctic continent (Mantyla \& Reid 1983, Gage \& Tyler 1991), no data on embryonic pressure tolerances are available for any shallow-water Antarctic invertebrate. It is known, however, that many species of Antarctic benthos are eurybathic in their vertical distribution (Brey et al. 1996), a feature that may be related to the unueually doop continental shelves around Antarctica and Cenozoic glacial history (Clarke \& Crame 1992). The dim of the present study was to determine the effects of temperature and pressure combinations on the early embryogenesis and later larval stages of the common Antarctic echinoid Sterechinus neumayeri. Specifically, we wished to de- termine if pressure would limit the ability of larvae of Sterechinus to disperse to bathyal depths through a cold isothermal water column.

The genus Sterechinus is comprised of 5 species, all found primarily in Antarctic waters (Hedgepeth 1969). $S$ agassizii is confined to the maritime Antarctic and $S$. diadema exclusively to the Kerguelen Islands. Of the continental Antarctic species, $S$. neumayeri is most common in shallow water down to $\sim 450 \mathrm{~m}$ depth, but may be found as deep as $850 \mathrm{~m}$, whereas $S$. antarcticus occurs at all depths from 100 to $1200 \mathrm{~m}$ (Brey \& Gutt 1991). These are remarkably broad distributions for essentially shallow-water sea urchins and may be permitted by the isothermal water column. S. dentifer is known only from 2 deep localities in the Indian Ocean sector of Antarctica (Hedgepeth 1969).

In shallow water, Sterechinus neumayeri can be the most abundant macrobenthic organism (Bosch et al. 1987. Brey \& Gutt 1991). In this species, the larvae are planktotrophic and the rate of development is very sensitive to temperature (Bosch et al. 1987. StanwellSmith \& Peck 1998). Moreover, larvae and embryos are extraordinarily stenothermal. Development occurs down to $-1.9^{\circ} \mathrm{C}$, whilst above $+1.7^{\circ} \mathrm{C}$ the number of non-viable eggs increases dramatically (StanwellSmith \& Peck 1998). Larvae of S. neumayeri are found in the plankton between November and February (Stanwell-Smith et al. 1998) and, although once believed to be demersal (Pearse \& Giese 1966), are now known to occur throughout the water column (Bosch et al. 1987). At the British Antarctic Base at Rothera Point, Adelaide Island, $S$ neumayeri is abundant in both the South and North Cove. The South Cove population spawns in November whereas the North Cove population will have spawning individuals to late January (S. Brockington pers. obs.).

Within the deep sea, juvenile echinoids and ophiuroids are often found outside the adult vertical range (Gage \& Tyler 1981, Sumida 1998) where they grow, and may even start gametogenesis, but die shortly afterwards (P.A. Tyler pers obs.). The very existence of such pseudopopulations shows that larvae of some echinoderms are capable of dispersing to and settling at depths greater than where the adults can survive. Permanent colonization therefore depends not only on the dispersal phase, but also on. the abilities of benthic stages to survive and reproduce under physical and dietary conditions that prevail in the deop soa.

\section{MATERIALS AND METHODS}

This study was carried out in the Bonner Laboratory of the British Antarctic Survey Base at Rothera 
on Adelaide Island to the west of the Antarctic Peninsula during January 1999. Samples of Sterechinus neumayeri were collected by divers in the North Cove of Rothera $\left(67^{\circ} 34^{\prime} \mathrm{S}, 68^{\circ} 07^{\prime} \mathrm{W}\right)$. Individuals were transported to the Bonner Laboratory in $25 \mathrm{l}$ plastic buckets and were placed in aquaria within 10 min of collection. Urchins were maintained in running seawater at $+0.9^{\circ} \mathrm{C}$ until used; this is the typical summer temperature for shallow-water habitats locally. To obtain gametes, urchins were inverted over finger bowls and injected with $1 \mathrm{ml}$ of $0.55 \mathrm{M} \mathrm{KCl}$. Urchins were left for $30 \mathrm{~min}$, as spawning was slow. Eggs were pipetted into fresh seawater and sperm were diluted with seawater at $+0.9^{\circ} \mathrm{C}$. Viability of eggs and sperm was checked before use. Eggs were fertilized with dilute sperm, left for $15 \mathrm{~min}$, then checked for fertilization envelopes.

Temperature/pressure effects on fertilized eggs. Fertilized eggs were used in a temperature/pressure matrix. Zygotes were pipetted into $8 \mathrm{ml}$ plastic scintillation vials filled to overflowing with seawater. Three replicate vials were assigned randomly to each pressure/temperature combination. Embryos were incubated at $-1.2( \pm 0.1)+0.9( \pm 0.1)$ and $+2.5^{\circ} \mathrm{C}\left( \pm 0.2^{\circ} \mathrm{C}\right)$ and, within each temperature, at $1,50,100,150$ and $200 \mathrm{~atm}$. The SI unit for pressure is the pascal ( $1 \mathrm{~atm}=10^{5} \mathrm{~Pa}$ ) but we have retained the use of atmospheres for clarity of presentation and recognition of the depths they represent (50 atm $\sim 500 \mathrm{~m}$ ). Because development rate in Sterechinus neumayeri is known to be slow (Bosch et al. 1987 ) cultures were examined only at 24 and $48 \mathrm{~h}$. At $24 \mathrm{~h}$, each culture was depressurized, examined and repressurized within $20 \mathrm{~min}$. Wherever possible, at least 50 embryos from each replicate were examined. The percentage of embryos at each cleavage stage was determined for each replicate.

Temperature/pressure effects on embryos and larvae. Cultures of embryos were maintained in $1 \mathrm{l}$ beakers partially submerged in flowing seawater at $+0.9^{\circ} \mathrm{C}$. Mesenchyme, prism and 4-arm plutei (as defined by Young et al. 1997) were incubated at $-1.2,+0.9$ and $+2.5^{\circ} \mathrm{C}$ and at 1 , $50,100,150,200$ and $250 \mathrm{~atm}$. Three replicates of each temperature/pressure combination were incubated for $24 \mathrm{~h}$, then examined. The number of dead and swimming larvae was recorded for each replicate.

\section{RESULTS}

Temperature/pressure effects on zygotes and early embryos at $24 \mathrm{~h}$

One-atmosphere controls developed normally at all 3 temperatures, attaining the 16 - and 32 -cell stages at $-1.2^{\circ} \mathrm{C}$ (Fig. 1) and the 32 -cell stage at +2.5 and $+0.9^{\circ} \mathrm{C}$. At $50 \mathrm{~atm}$, embryos at $-1.2^{\circ} \mathrm{C}$ attained no more than the 4 -cell stage, while embryos incubated at +2.5 and $+0.9^{\circ} \mathrm{C}$ reached the 32 -cell stage. At $100 \mathrm{~atm}$, no cleavage occurred at $-1.2^{\circ} \mathrm{C}$, but embryos were at the 4 -cell stage at $+0.9^{\circ} \mathrm{C}$ and at the 16 and 32 -cell stages at $+2.5^{\circ} \mathrm{C}$. At $150 \mathrm{~atm}$ and $+2.5^{\circ} \mathrm{C}$, embryonic development was slightly slower than at lower pressures, with embryos attaining only the 16 -cell stage. This effect was even more dramatic at +0.9 and $-1.2^{\circ} \mathrm{C}$, where a few zygotes initiated first cleavage, but most remained as uncleaved zygotes. At $200 \mathrm{~atm}$, there was no normal cleavage at any temperature. Uncleaved zygotes at the

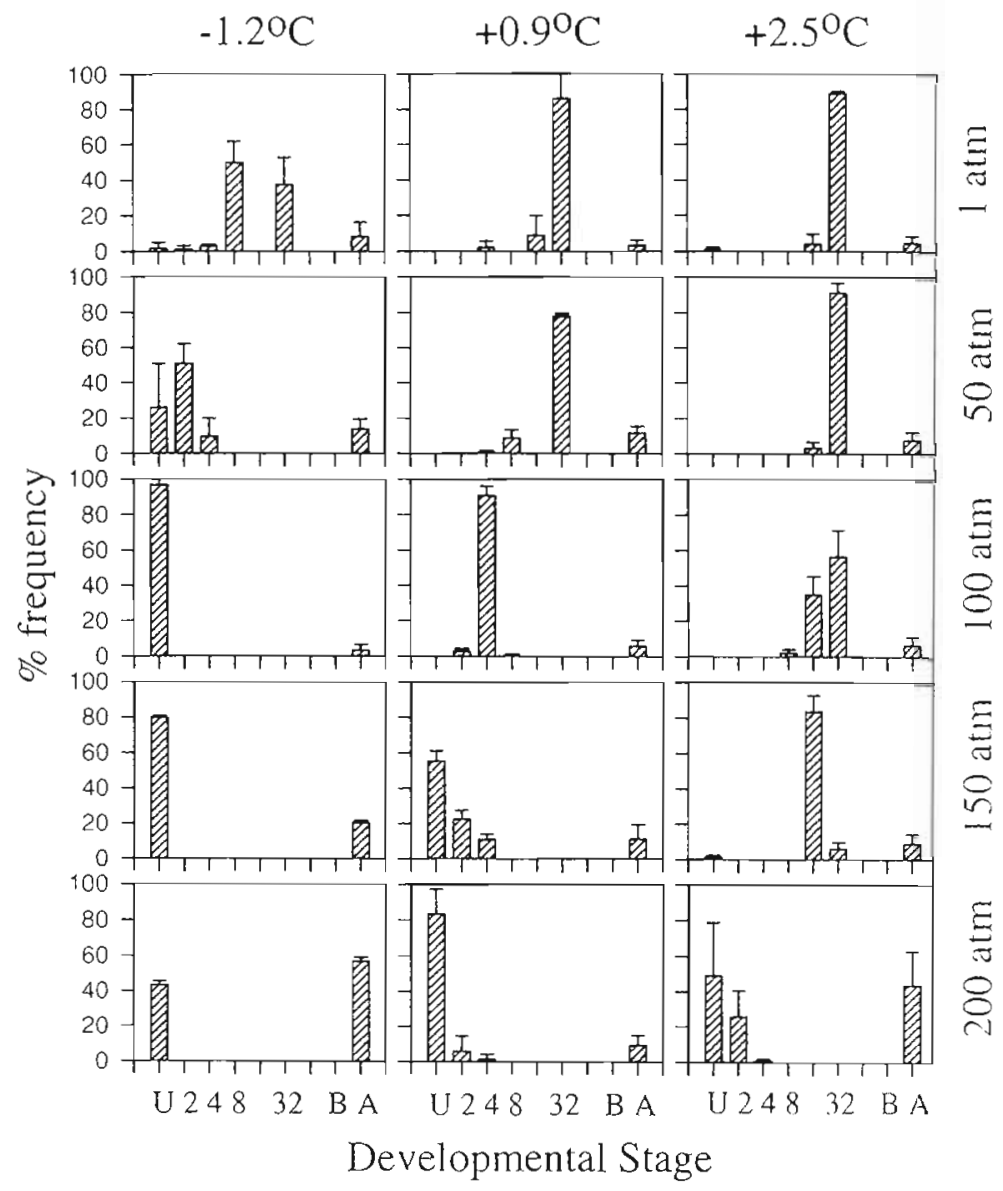

Fig. 1. Sterechinus neumayeri embryos incubated at $+2.5,+0.9$ and $-1.2^{\circ} \mathrm{C}$ at 1 to $200 \mathrm{~atm}$ for $24 \mathrm{~h}$. Histograms represent \% mean and SD. Development stages are (U) Uncleaved, 2 to 64 cell, (B) Blastula and (A) Abnormal 
2 higher temperatures looked normal after $24 \mathrm{~h}$, but at $-1.2^{\circ} \mathrm{C}$ and $200 \mathrm{~atm}$, we observed a number of zygotes with unusually rough surfaces. Abnormal embryos at lower pressures generally cleaved, but the blastomeres were in abnormal spatial configurations.

\section{Temperature/pressure effects on zygotes and early embryos at $48 \mathrm{~h}$}

At $-1.2^{\circ} \mathrm{C}$, the control cultures at $1 \mathrm{~atm}$ yielded blastulae, the 50 atm culture had a mixture of 64 -cell stages and blastulae, and the $100 \mathrm{~atm}$ cultures contained a few 2- and 4-cell embryos. Most zygotes or embryos at 100 atm were uncleaved or abnormally cleaved (partially cleaved, or irregularly cleaved) (Fig 2). At 150 and 200 atm, no zygotes had cleaved, and some had a rough surface. At $+0.9^{\circ} \mathrm{C}$, embryos had reached the blastula stage from 1 to $100 \mathrm{~atm}$, but had become abnormal at higher pressures. These abnormalities included a mixture of disaggregated blas-

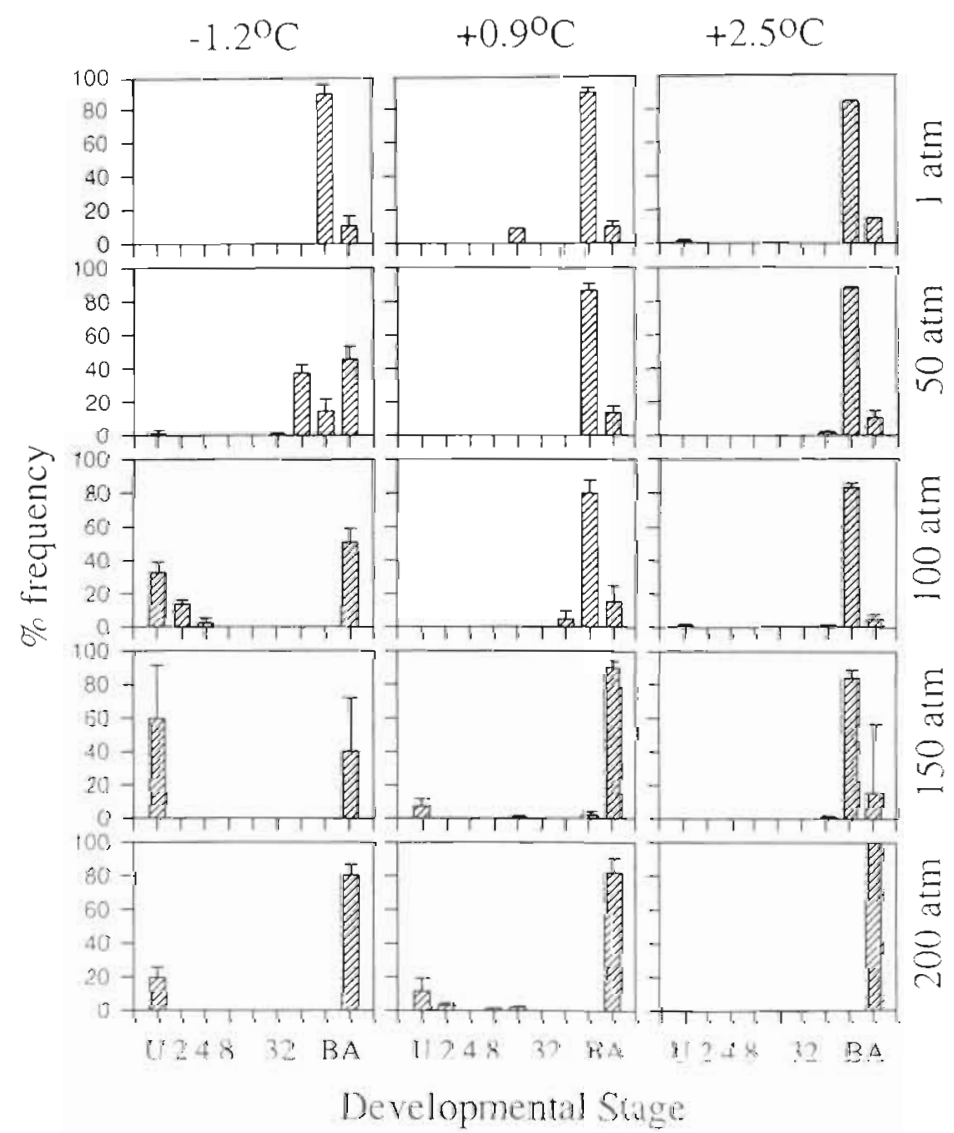

Fig. 2. Sterechinus neumayeri embryos incubated at +2.5 . +09 and $-1.2^{\circ} \mathrm{C}$ at 1 to $200 \mathrm{~atm}$ for $48 \mathrm{~h}$. Histograms represent \% mean and SD. Development stages ate (U) Uncleaved, 2 to 64 cell, (B) Blastula and (A) Abnormal tomeres in embryos that had cleaved abnormally, and uncleaved zygotes with rough surfaces. At $+2.5^{\circ} \mathrm{C}$, embryos attained the blastula stage at all pressures from 1 to $150 \mathrm{~atm}$. The zygotes incubated at $200 \mathrm{~atm}$ remained mostly uncleaved and showed an irregular surface. Those few embryos at 200 atm that had undergone first cleavage after $24 \mathrm{~h}$ were showing irregular cleavages after $48 \mathrm{~h}$.

\section{Temperature/pressure effects on blastulae at $24 \mathrm{~h}$}

At $+2.5^{\circ} \mathrm{C}$ more than $90 \%$ of all embryos were swimming after $24 \mathrm{~h}$ incubation at pressures up to and including $250 \mathrm{~atm}$ (Fig. 3). Mortality at $+0.9^{\circ} \mathrm{C}$ was only slightly higher (most cultures with more than $70 \%$ swimming) except at $200 \mathrm{~atm}$, where an average of $24 \%$ of embryos was still swimming after incubation. At $-1.2^{\circ} \mathrm{C}$ the number of swimming embryos remained high from 1 to $150 \mathrm{~atm}$ but declined to $46 \%$ at $200 \mathrm{~atm}$. Only a single swimming blastula survived at $250 \mathrm{~atm}$.

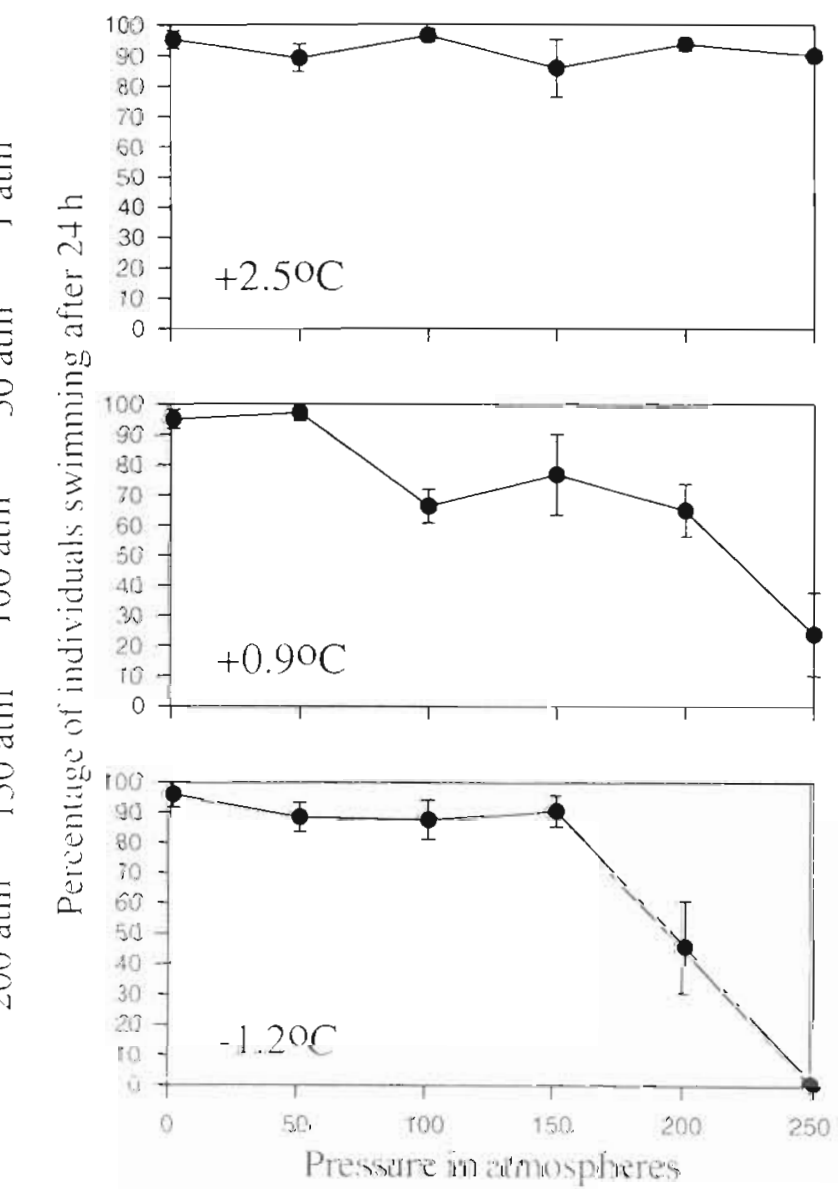

Fig. 3. Sterechinus neumayeri. Survival of blastulae imes. enchyme stage) at $+2.5,+0.9$ and $-1.2^{\circ} \mathrm{C}$ at 1 to $250 \mathrm{~atm}$ for $24 \mathrm{~h}$. Data are mean and SD of 3 replicates 


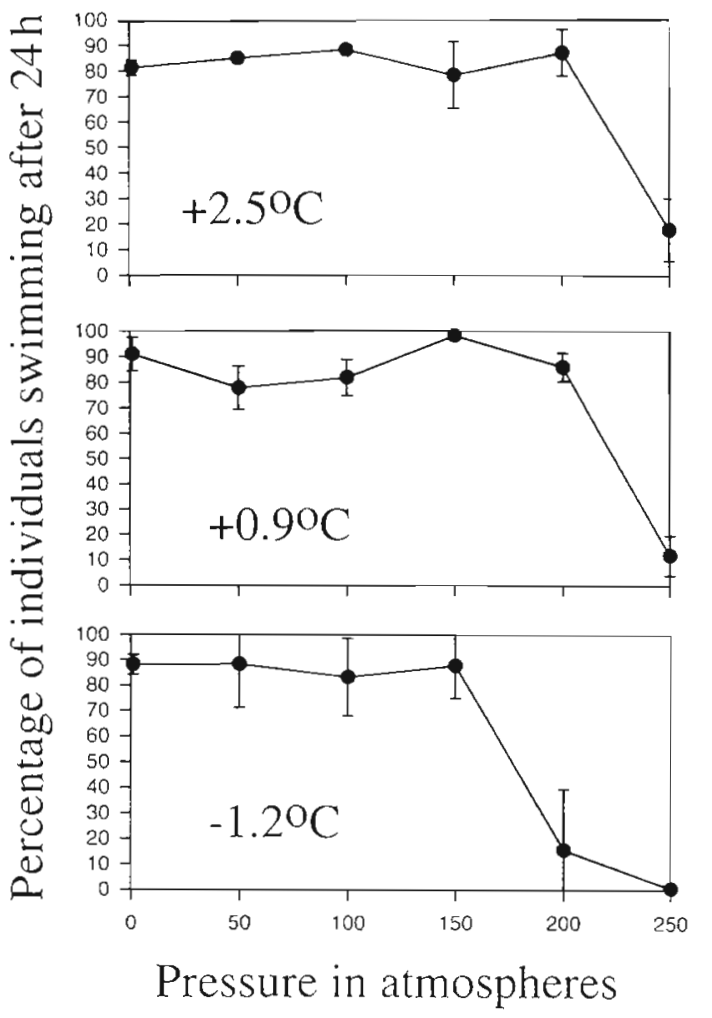

Fig. 4. Sterechinus neumayeri. Survival of prisms at $+2.5,+0.9$ and $-1.2^{\circ} \mathrm{C}$ at 1 to $250 \mathrm{~atm}$ for $24 \mathrm{~h}$. Data are mean and SD of 3 replicates

\section{Temperature/pressure effects on prisms at $24 \mathrm{~h}$}

At $+2.5^{\circ} \mathrm{C}$ and $+0.9^{\circ} \mathrm{C}$, the number of swimming prisms remained high $(>75 \%)$ after incubation at 1 to $200 \mathrm{~atm}$, but at $250 \mathrm{~atm}$, the number of surviving prisms was reduced to $<20 \%$ (Fig. 4). At $-1.2^{\circ} \mathrm{C}$, the percentage of survivors remained high between 1 and $150 \mathrm{~atm}$ but was reduced substantially to $<16 \%$ at $200 \mathrm{~atm}$ and $<1 \%$ (2 prisms total in all 3 replicates) at $250 \mathrm{~atm}$

\section{Temperature/pressure effects on 4 -arm plutei at $24 \mathrm{~h}$}

Survivorship of 4 -arm plutei was variable among treatments (Fig. 5). At +2.5 and $+0.9^{\circ} \mathrm{C}$, survival was $>70 \%$ at 1 and 50 atm but substantially lower at pressures above $100 \mathrm{~atm}$. At $-1.2^{\circ} \mathrm{C}$, survival had decreased to $58 \%$ at $50 \mathrm{~atm}$, remained low between 100 and $200 \mathrm{~atm}$, and declined to zero at $250 \mathrm{~atm}$.

\section{DISCUSSION}

The origin of the deep-sea fauna has been a point of discussion for decades. One view maintains that many

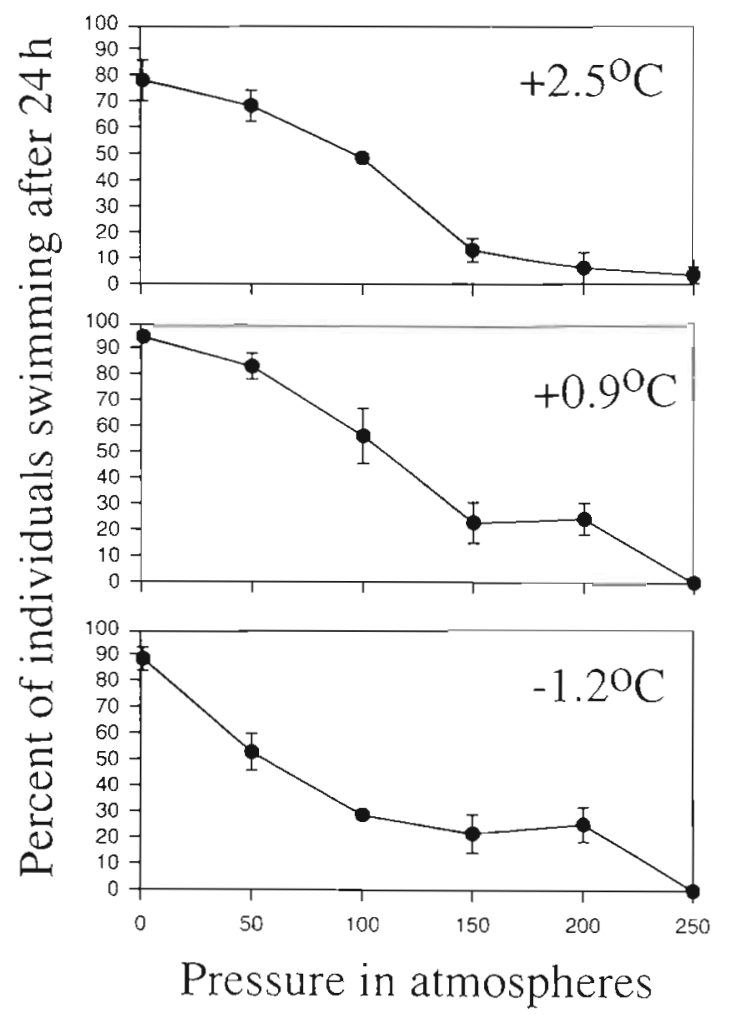

Fig. 5. Sterechinus neumayeri. Survival of 4 -arm plutei at $+2.5,+0.9$ and $-1.2^{\circ} \mathrm{C}$ at 1 to 250 atm for $24 \mathrm{~h}$. Data are mean and SD of 3 replicates

of the major deep-sea taxa originated within and radiated from the deep sea (Hessler \& Thistle 1975). Proponents of the alternative view, that animals invaded the deep sea from shallow water, have suggested that invasions could have occurred either during the Mesozoic or early Cenozoic. During these eras the water column was vertically homogenous and warm (Menzies et al. 1973, Hessler \& Wilson 1983). More recently invasion of the deep-sea could have taken place through near-isothermal cold water at high latitudes (Kussakin 1973, Menzies et al. 1973). Both possibilities require adaptation to high pressure, and the former additionally requires that animals slowly adapt to cold temperatures (Clarke 1983).

Experimental work on the pressure and temperature tolerances of embryos and larvae of shallow-water echinoids from the northern Mediterranean (Young et al. 1997) indicates that larvae should be able to enter the deep sea through a warm water column. In this region, Western Mediterranean Deep Water is formed during the winter when mistral winds from the Maritime Alps cool the sea surface and convection overturns the water column to form a nearly homogenous water column to $2500 \mathrm{~m}$ depth. Embryos and larvae of the shallow-water echinoids Paracentrotus lividus, 
Arbacia lixula, and Sphaerechinus granularis were able to tolerate pressures as high as $150 \mathrm{~atm}$ at $15^{\circ} \mathrm{C}$. Lower temperatures $\left(<11^{\circ} \mathrm{C}\right)$ exacerbated the effects of pressure. Thus, invasion of the deep sea by these species would require relatively high temperatures initially, followed by slow adaptation to the more normal cold temperatures that prevail there. Although $P$. lividus and $A$. lixula have very shallow distributions, living larvae have been collected from depths as great as $400 \mathrm{~m}$ (Pedrotti 1990), indicating that invasion of deep waters could actually occur within a single generation (Young et al. 1997).

In the Norwegian Sea, North Atlantic Deep Water is formed during winter when high salinity surface water from the North Atlantic cools and sinks to form a deep homogenous water column. This water flows south over the Scotland-Faroes-Iceland-Greenland Ridge, sinks and spreads throughout the world's ocean as a deep, cold water mass (Gage \& Tyler 1991). Tyler \& Young (1998) have examined the temperature/pressure tolerance of embryos and larvae of the shallowliving Echinus esculentus, shallow and bathyal ( $900 \mathrm{~m}$ depth) population of $E$. acutus and lower bathyal $(\sim 2000 \mathrm{~m})$ populations of E. affinis. Embryos and larvae of both E. esculentus and $E$. acutus tolerated pressures up to more than 250 atm, which is far beyond those encountered in the adult range. Unlike the Mediterranean urchins, developmental arrests and abnormalities decreased with lower temperatures, suggesting that single-generation invasion of the deep sea could be difficult for temperate species that normally reproduce between 5 and $15^{\circ} \mathrm{C}$. Evidence that slower invasion may take place at these latitudes comes from embryos of the bathyal population of E. acutus. These embryos developed more rapidly at cold temperatures and high pressures than did embryos of shallow conspecifics, suggesting an adaptation to depth. Truly barophilic embryos were observed in E. affinis, which failed to cleave at low pressure and showed maximal development above 100 atm (Young \& Tyler 1993، Tyler \& Young 1998)

The deepest (and most dense) water mass in the world's oceans is formed around Antarctica where the very dense, cold, high-saline water is formed by freezing of the surface waters. Antarctic Bottom Water (a generic term for cold water formed in the Weddell Sea, the Ross Sea and off Terre Adelie coast; Gage \& Tyler 1991) has a temperature of $-0.4^{\circ} \mathrm{C}$ and a salinity of 34.66. Analysis of the temperature/messure tnlerance of Sierechinus neumayeri embryos shows that decreasing temperature and increasing pressure, even over the very stenothermal range of the adult, have variable effects. As previously observed (Bosch et al. 1987, Stanwell-Smith \& Peck 1998), 1 atm controls showed a decrease in the rate of development with decreasing temperature. In contrast to Stanwell-Smith \& Peck (1998), we observed normal development at $+2.5^{\circ} \mathrm{C}$, almost $1^{\circ} \mathrm{C}$ above the temperature at which they obtained normal development. At $50 \mathrm{~atm}$ embryonic development was slowed at $-1.2^{\circ} \mathrm{C}$, and at $>100$ atm zygotes remained uncleaved. After $24 \mathrm{~h}$ at +0.9 and $+2.5^{\circ} \mathrm{C}$ development was normal, although retarded, to $150 \mathrm{~atm}$. At $48 \mathrm{~h}$ development was only normal up to pressures of $150 \mathrm{~atm}$ at $+2.5^{\circ} \mathrm{C}$. At $48 \mathrm{~h}$ embryos were abnormal from $100 \mathrm{~atm}$ at $+0.9^{\circ} \mathrm{C}$ to $200 \mathrm{~atm}$ at $+2.5^{\circ} \mathrm{C}$. Interestingly, the potential effect of this pattern on deep-sea invasion potential varies between north and south polar species because of the thermal structure of the water column. In the North Atlantic, water becomes colder with depth, increasing the pressures that the embryos can tolerate. By contrast, the temperature in Antarctic seas may increase with depth (depending on season), the coldest water being near the surface where ice melts, and the water warming at greater depths as various water masses $\operatorname{mix.}$

The response of later stages of embryonic development in Sterechinus neumayeri are in contrast to the effects seen in the Mediterranean and North Atlantic. Of the 3 stages tested, the mesenchyme blastulae were the most tolerant of pressure particularly at $+2.5^{\circ} \mathrm{C}$ but were able to tolerate $150 \mathrm{~atm}$ at $-1.2^{\circ} \mathrm{C}$. Prisms were tolerant of pressure to $200 \mathrm{~atm}$ at +0.9 and $+2.5^{\circ} \mathrm{C}$, but only to $100 \mathrm{~atm}$ at $-1.2^{\circ} \mathrm{C}$. The reason for this non-linear response is not known. The 4 -arm plutei showed the least tolerance to pressure increase, with a steady decline in survival with increased pressures, resulting in $<20 \%$ survival at pressures greater than $150 \mathrm{~atm}$. The reduced survival at $1 \mathrm{~atm}$ at $+2.5^{\circ} \mathrm{C}$ may be a result of exceeding the upper temperature tolerance levels of larvae of $S$. neumayeri.

These data imply that embryonic stages of Sterechinus neumayeri have the ability to invade deep water at temperatures within their normal development range. The extreme cold water of the Antarctic $\left(-1.9^{\circ} \mathrm{C}\right.$ in Western Shelf Water of the Weddell Seal may retard the ability of larvae to tolerate pressure, although development will occur at that temperature (Bosch et al. 1987, Stanwell-Smith \& Peck 1998). However, in deeper water, typical Antarctic water temperatures are on the order of $\sim 0^{\circ} \mathrm{C}$ and we believe this temperature would not inhibit larval invasion of deep water. Because of the increase in water temperature with depth, we conclude that echinoid larvae are moro likely to invade the deep sea during a single generation in Antarctic waters than in either the Norwegian or Mediterranean Seas.

As observed in the genus Echinus in the North Atlantic (Tyler et al. 1996, Tyler \& Young 1998) congeneric species with overlapping vertical ranges can 
be found for the genus Sterechinus in the Antarctic. Two deep water forms are known: $S$. antarcticus overlaps the lower depth distribution of $S$. neumayeri in the Weddell Sea (Brey \& Gutt 1991) and S. dentifer is found in the, as yet, poorly sampled Indian Ocean sector of Antarctica. The reason an analagous situation is not found in the Mediterranean, the echinoids being confined to shallow water, is perhaps the young age of the Mediterranean Sea ( -5 million yr). Most of the deep-water fauna is believed to have invaded from the Atlantic through the Straits of Gibraltar rather than being formed in the Mediterranean and there has been insufficient time for the evolution of an endemic deepwater fauna (Pérès 1985). In contrast, the circumAntarctic benthic fauna is very old (Lipps \& Hickman 1982, Clarke \& Crame 1989).

We believe these empirical data suggest that the embryos and larvae from at least 1 taxonomic group are capable of invading deep water along either a warm- or cold-water isotherms. It is significant that the formation of a deep-water mass coincides temporally with spawning and larval development in these Antarctic species.

Acknowledgements. We wish to acknowledge the hospitality of all personnel at the BAS Base at Rothera on Adelaide Island, especially Mike Dinn, the Base Commander, Simon Brockington, Dawn Powell, Jenny Beaumont, Steve Dunkerley and all members of the dive team. Dawn Powell is thanked for establishing cultures of Sterechinus neumayeri embryos before the arrival of P.A.T. at Rothera. We sincerely thank The Royal Society for the financial support that made this study possible.

\section{LITERATURE CITED}

Bosch 1, Beauchamp KA, Steele ME, Pearse JS (1987) Development, metamorphosis, and seasonal abundance of embryos and larvae of the Antarctic sea urchin Sterechinus neumayeri. Biol Bull 173:126-135

Brey T, Gutt J (1991) The genus Sterechinus (Echinodermata: Echinoidea) on the Weddell Sea shelf and slope (Antarctica): distribution, abundance and biomass. Polar Biol 11 . $227-232$

Brey T, Dahm C, Gorny M, Klages M, Stiller M, Arntz WE (1996) Do Antarctic benthic invertebrates show an extended level of eurybathy? Antarct Sci 8:3-6

Carney RS, Haedrich RL, Rowe GT (1983) Zonation of fauna in the deep-sea. In: Rowe GT (ed) The Sea, Vol 8. Wiley Interscience, New York, p 371-398

Clarke A (1983) Life in cold water: the physiological ecology of polar marine ectotherms. Oceanogr Mar Biol Annu Rev 21:341-453

Clarke A, Crame JA (1989) The origin of the Southern Ocean marine fauna. In: Crame JA (ed) Origins and evolution of the Antarctic biota. Geological Society Special Publication No. 47. The Geological Society, London, p 253-268

Clarke A, Crame JA (1992) The Southern Ocean benthic fauna and climate change: a historical perspective. Phil Trans R Soc Lond B 338:299-309
Gage JD, Tyler PA (1981) Non-viable seasonal settlement of the larvae of the upper bathyal brittlestar Ophiocten gracilis in the Rockall Trough abyssal. Mar Biol 64:153-161

Gage JD, Tyler PA (1991) Deep sea biology: a natural history of organisms at the deep sea floor. Cambridge University Press, Cambridge

Hedgepeth JW (1969) Introduction to Antarctic zoogeography. Antarctic Map Folio Series 11:1-44

Hessler RR, Thistle D (1975) On the place of origin of deepsea isopods. Mar Biol 32:155-165

Hessler RR, Wilson GDF (1983) The origin and biogeography of the malacostracan crustaceans in the deep sea. In: Sims RW, Price JH, Whalley PES (eds) Evolution in time and space: the emergence of the biosphere. Academic Press. New York, p 227-254

Kinne $O$ (1972) Pressure: general introduction. In: Kinne $O$ (ed) Marine Ecology, Vol 1, Part 3. Wiley Interscience, New York, p 1323-1360

Kussakin OG (1973) Peculiarities of the geographical and vertical distribution of marine isopods and the problem of deep-sea fauna origin. Mar Biol 23:19-34

Lipps JH, Hickman CS (1982) Origin, age, and evolution of Antarctic and deep-sea faunas. In: Ernst WG Morin JG (eds) The environment of the deep sea. Prentice Hall Inc Englewood Cliffs, p 324-356

Mantyla AW, Reid JL (1983) Abyssal characteristics of the World Ocean waters. Deep Sea Res 30:805-833

Marsland DA (1938) The effects of high hydrostatic pressure upon cell division in Arbacia eggs. J Cell Comp Physiol 12: $57-70$

Marsland DA (1950) The mechanism of cell division: temperature pressure experiments on the cleaving eggs of Arbacia punctulata. J Cell Comp Physiol 36:205-227

Marsland DA (1970) Pressure temperature studies on the mechanisms of cell division. In: Zimmerman AM (ed) High pressure effects on cellular processes. Academic Press, New York, p 260-312

Menzies RH, George RY, Rowe GT (1973) Abyssal environment and ecology of the world oceans. Wiley Interscience, New York

Pearse JS, Giese, AC (1966) Food, reproduction and organic constitution of the common Antarctic echinoid Sterechinus neumayeri (Meissner). Biol Bull 130:387-401

Pedrotti ML (1990) Etudes des processus biologiques et des facteurs physiques responsables de la dispersion et du recrutement des larves méroplanctoniques. Modèle: les larves d'échinoderms. These de Doctoral de l'Universite $P$ \& $M$ Curie, Paris

Pérès JM (1985) History of the Mediterranean biota and colonization of the depths. In: Margalef $R$ (ed) The western Mediterranean. Pergamon Press, Oxford, p 198-232

Somero GN (1992) Adaptations to high hydrostatic pressure. Annu Rev Physiol 54:557-577

Stanwell-Smith D. Peck LS (1998) Temperature and embryonic development in relation to spawning and field occurrence of larvae of three Antarctic echinoderms. Biol Bull 194:44-52

Stanwell-Smith D, Peck LS, Clarke A, Murray AWA, Todd CD (1998) The distribution, abundance and seasonality of pelagic marine invertebrate larvae in the maritime Antarctic. Phil Trans R Soc 353:1-14

Sumida P (1998) Post-larval development in deep-sea echinoderms. PhD thesis, University of Southampton

Swezwy RR, Schmidt T, Epel D (1987) Effects of hydrostatic pressure on actin assembly and initiation of amino acid transport upon fertilization of sea urchin eggs. In: Jan-

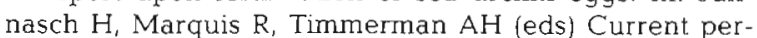


spectives in high pressure biology. Academic Press, London, p 95-109

Tyler PA, Young CM (1998) Temperature and pressure tolerances in dispersal stages of the genus Echinus (Echinodermata: Echinoidea): prerequisites for deep-sea invasion and speciation. Deep-Sea Res II 45:253-277

Tyler PA, Young CM, Serafy DK (1996) Distribution, diet and reproduction in the genus Echinus: evidence for recent diversification? In: Emson $\mathrm{R}$, Smith $\mathrm{A}$, Campbell AC (eds) Echinoderm research 1995. Balkema, Rotterdam, p 29-38

Young CM. Tyler PA (1993) Embryos of the deep-sea echinoid Echinus affinis require high pressure for development. Limnol Oceanogr 38:178-181

Young CM, Tyler PA, Gage JD (1996a) Vertical distribution

Editorial responsibility: Roger Hughes (Contributing Editor), Bangor, Wales, UK correlates with embryonic pressure tolerances in the deep-sea asteroid Plutonaster bifrons. J Mar Biol Assoc UK 76:749-757

Young CM. Tyler PA, Emson RH (1996b) Embryonic pressure tolerances of bathyal and littoral echinolds from the tropical Atlantic and Pacific Oceans. In: Emson RH, Smith AB, Campbell AC (eds) Echinoderm research 1995. Balkema, Rotterdam, p 325-334

Young CM, Tyler PA, Fenaux L (1997) Potential for deep sea invasion by Mediterranean shallow water echinoids: pressure and temperature as stage-specific dispersal barriers. Mar Ecol Prog Ser 154:197-209

Zimmerman AH, Marsland DA (1964) Cell division: effects of pressure on the mitotic mechanisms of marine eggs (Arbacia punctulata). Exp Cell Res 35:293-302

Submitted: April 26, 1999; Accepted: August 4, 1999 Proofs received from author(s): January 14, 2000 